\title{
Pediatric valve-sparing aortic root replacement: Approaching perfection
}

\author{
Harold M. Burkhart, MD, ${ }^{a}$ Jess L. Thompson, MD, ${ }^{a}$ and Mathew Campbell, $\mathrm{MD}^{\mathrm{b}}$
}

\footnotetext{
From the a Division of Cardiovascular and Thoracic Surgery, University of Oklahoma Health Sciences Center, Oklahoma City, Okla; and ${ }^{\mathrm{b}}$ Section of Pediatric Cardiology, University of Oklahoma Health Sciences Center, Oklahoma City, Okla.

Disclosures: Authors have nothing to disclose with regard to commercial support.

Received for publication Oct 28, 2018; accepted for publication Oct 29, 2018; available ahead of print Nov 30, 2018.

Address for reprints: Harold M. Burkhart, MD, Division of Cardiovascular and Thoracic Surgery, University of Oklahoma Health Sciences Center, PO Box 26901, WP-2230 Oklahoma City, OK 73105 (E-mail: Harold-burkhart@ouhsc.edu).

J Thorac Cardiovasc Surg 2019;157:1110-1

$0022-5223 / \$ 36.00$

Copyright (c) 2018 by The American Association for Thoracic Surgery

https://doi.org/10.1016/j.jtcvs.2018.10.132
}

Over the past 3 decades, aortic root replacement surgery has evolved with much attention given to preserving the aortic valve when possible. Valve-sparing operations including the reimplantation and remodeling procedures, along with modifications, have gained support with the techniques being expanded to treat aneurysmal aortic disease in children. The benefits of conserving the valve are clear: avoidance of complications associated with anticoagulation therapy. Concerns over the development of aortic valve insufficiency or a pseudoaneurysm necessitating further surgery have been the primary arguments against these operations. ${ }^{1}$

In this issue of the Journal, Fraser and colleagues, ${ }^{2}$ present single-institution data from a 20 -year period describing 100 consecutive cases of valve-sparing aortic root replacement (VSRR) in patients aged less than 18 years (median, 13.6 years). As expected, the majority of the patients had underlying connective tissue disease, such as Marfan syndrome $(51 \%)$ or Loeys-Dietz syndrome (39\%). Although 4 different procedures were used to achieve a VSRR over the past 20 years, the majority $(84 \%)$ of patients underwent the reimplantation technique. ${ }^{3}$ Concomitant aortic valve repair was performed in 9 patients undergoing VSRR. Perioperative mortality was only $2 \%$, with both patients having connective tissue disease. With a median follow-up of 4.7 years, 7 additional patients died, 4 of whom died of complications related to connective tissue disease. Reimplantation VSRR was found to be durable with a 5-year freedom from reintervention or $94 \%$. Six patients required late reintervention for the development of a pseudoaneurysm. ${ }^{4}$ A total of 4 patients $(4.8 \%)$ who underwent the reimplantation VSRR required late aortic valve replacement because of the development of annular dilatation and significant aortic insufficiency. Of note, none of the 12 patients with a bicuspid aortic valve required subsequent reoperation for aortic valve insufficiency.

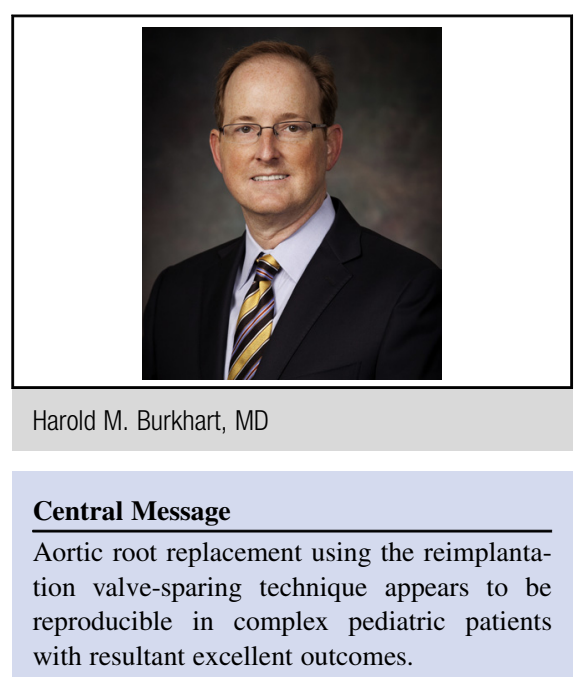

See Article page 1100.

The significance of the article is understandable in that Fraser and colleagues ${ }^{2}$ present the largest experience with VSRR in the pediatric population. The group at Johns Hopkins have a well-deserved reputation as being the experts in VSRR surgery. Their reimplantation technique appears reproducible, even in pediatric patients with aortic valve insufficiency or a bicuspid aortic valve. The possibility of aortic valve replacement after the reimplantation VSRR is low. In addition, the authors provide valuable surgical technical tips when performing the reimplantation VSRR. Furthermore, the authors have gained an incredible amount of experience in the management of patients with connective tissue aortopathies. Through this understanding and to our benefit, they have been able to better define their guidelines for timing of aortic root replacement.

There are a few limitations to the study. David and colleagues ${ }^{5}$ demonstrated that patients with Marfan syndrome undergoing aortic valve-sparing root replacement have progressive aortic insufficiency over time. Given that the median follow-up in the current study is 4.7 years, one must acknowledge that the risk for surgical intervention may be higher with time. In addition, these are the results of a high-volume center performing a technically demanding procedure, and lowervolume centers may not be able to duplicate the results. ${ }^{6}$ Last, more detail on the failures of the patients undergoing reimplantation VSRR may have been helpful. One has to wonder about the mechanism of annular dilation and the selective need for better aortic root stabilization. 
Fraser and colleagues ${ }^{2}$ show that the reimplantation VSRR is an effective, reproducible technique in children. With midterm follow-up, the risk for surgical reintervention is low. Modifications in annular stabilization in select patients may further improve the excellent outcomes. Longer follow-up on aortopathy in pediatric patients with connective tissue disorder will undoubtedly aid in defining surgical timing and the need for any adjustments.

\section{References}

1. Coselli JS, Volguina IV, LeMaire SA, Sundt TM, Connolly HM, Stephens EH, et al. Early and 1-year outcomes of aortic root surgery in patients with Marfan syn- drome: a prospective, multicenter, comparative study. J Thorac Cardiovasc Surg. 2014; 147:1758-67.

2. Fraser CD, Liu RH, Zhou X, Patel ND, Lui C, Pierre AS, et al. Valve-sparing aortic root replacement in children: outcomes from 100 consecutive cases. J Thorac Cardiovasc Surg. 2019;157:1100-9.

3. Cameron D, Vricella L. Valve-sparing aortic root replacement in children. Oper Tech Thorac Cardiovasc Surg. 2013;20:31-45.

4. Liu RH, Fraser CD III, Zhou X, Cameron DE, Vricella LA, Hibino N. Pseudoaneurysm formation after valve sparing root replacement in children with LoeysDietz syndrome. J Card Surg. 2018;33:339-43.

5. David TE, David CM, Manlhiot C, Colman J, Crean AM, Bradley T. Outcomes of aortic valve-sparing operations in Marfan syndrome. J Am Coll Cardiol. 2015;66: 1445-53.

6. Hughes GC, Zhao Y, Rankin JS, Scarborough JE, O’Brien S, Bavaria JE, et al. Ef fects of institutional volumes on operative outcomes for aortic root replacement in North America. J Thorac Cardiovasc Surg. 2013;145:166-70. 